\title{
VIOLENT PROTEST AT LOCAL GOVERNMENT LEVEL IN SOUTH AFRICA: REVOLUTIONARY POTENTIAL?
}

\author{
Prof Mike Hough \\ Director: Institute for Strategic Studies, \\ University of Pretoria
}

\begin{abstract}
In this article, a broad overview of the main causes and theories of revolution is presented. The objective is to obtain, by analysing recent events in South Africa pertaining to the ongoing protest actions over service delivery at local government level, some indication of revolutionary potential in South Africa. In this regard, there seem to be two basic views, namely on the one hand, that violent protest action at local level can lead to revolutionary activity, and on the other hand, that the protest can be contained but aspects of policy will have to be adapted.
\end{abstract}

\section{Introduction}

Following ongoing and often violent protest action mainly aimed at poor service delivery on local government level in South Africa, the situation was seen in some quarters as having the potential to escalate into a revolution, and that revolutionary potential was clearly visible. The disintegration of order is an early warning sign of a revolutionary situation.

The aim of this article is to broadly examine the concept of revolutionary potential and the causes of revolution, and to apply this to the current South African situation with specific reference to violent protest at local government level. Official views and reactions to the protests are also briefly addressed.

It should of course be kept in mind that while revolutionary potential is some indication of the likelihood of revolutionary activity, there are other factors that may determine the commencing and eventual outcome of the activity. 


\section{The concept of revolution and revolutionary potential}

\section{Conceptual analysis}

A wide spectrum of concepts are often linked to revolution, for instance internal war, rebellion, anti-colonial wars, guerrilla warfare, coups, insurrection, terror, insurgency and riots. In some cases, the concept of 'internal war' or 'rebellion' is used as the general umbrella term which, for instance, covers revolutions, civil wars, coups, riots and strikes. ${ }^{1}$

In other views, manifestations of political violence (both in terms of mass and small group political violence) can be arranged on an escalation ladder, depicting rising degrees of intensity. As far as mass political violence is concerned, the first stage consists of riots and street violence, followed by armed rebellion or resistance, followed by revolution and civil war. ${ }^{2}$

The concepts of 'insurgency' and 'revolutionary warfare' are regarded as being largely interchangeable. ${ }^{3}$ Snow $^{4}$ also defines 'insurgencies' as civil wars, where the term refers to "organised armed violence between groups within a state for the purpose of overthrowing and replacing an existing regime, or to secede from an existing state". 5

'Revolutionary warfare' refers to one form of revolutionary activity, namely protracted struggle during which irregular military tactics are combined with psychological and political operations. A revolutionary coup or a mass uprising would present alternative forms of revolutionary activity. ${ }^{6}$

Terrorism could either be the main method of warfare, or part of a broader insurgency. In the former case, it could be of a revolutionary variety, or of a subrevolutionary nature (not aimed at overthrowing a government, but coercing government to change certain policies). In the latter case, where terrorism forms part of a broader insurgency, it is viewed as serving the purpose of tying down the security forces and helping to create a climate of fear and collapse. Currently, most insurgencies tend to include terror tactics, rather than guerrilla warfare proper (that tends to avoid civilian targets). Classic guerrilla leaders tended to oppose indiscriminate terror. Relatively few protests that start with acts of terror, however, develop into full-scale insurgencies. Many protests simply do not have the critical mass (in terms of popular support) and other resources for such a campaign, and some also have limited or no external support. ${ }^{7}$

\section{Some causes of revolution and terrorism}

A distinction between the underlying causes or preconditions of revolutions, and socalled "accelerators" or trigger factors that serve as the short-term, final, or 
immediate causes of revolution is often made. In the case of both preconditions and accelerators, it should be remembered that, at most, varying degrees of probability could be demonstrated but not proven without any doubt.

Conditions in a specific country at a specific time may contribute towards establishing revolutionary potential, whereas similar conditions in another situation may not. Some conditions may lead to political unrest and political violence or even sub-revolutionary terror, or an attempted coup, but not to revolutionary warfare or revolutionary terror. In other cases, movements of pure terror could arise, with no clear revolutionary programme.

\section{Underlying causes or preconditions}

A broad overview of some of the causes thought to contribute towards the growth of revolutionary potential, reveals that some of these have been elevated to the level of theories of revolution (or hypotheses), while others are based on casual inferences based on case-studies, but not yet formulated as theoretical constructs.

\section{Cultural cleavage}

This includes racial and ethnic divisions, and it can be exacerbated by immigration of foreigners that are culturally different, or even by internal migration. Ethnic or racial cleavages that are reinforced by religious, linguistic or economic differences form specific threats to stability. In addition, if a culture of violence has been established in a country in the past, it could serve to legitimate violence in the future. ${ }^{8}$

\section{Land tenure and economic development}

Most revolutionary movements in modern history have occurred in agricultural societies where an uneven distribution of land existed. Where land ownership is linked to foreign interests, it is also linked to the issue of anticolonialism.

The growth of a market economy, as far as agriculture is concerned, often entails the destruction of traditional social values and authority patterns. Revolutionary potential is in this regard not the poverty of the peasants per se, but the threats to relative security and traditional status as a result of economic change. Urbanisation and industrialisation linked to modernisation, increases revolutionary potential. $^{9}$

\section{Political adaptation}

Failure by opposition groups to obtain reform through constitutional politics or inability of governments to adapt to modernisation, increases revolutionary 
potential. However, democratisation also requires the development of a political culture supportive of democracy. ${ }^{10}$

Social status

Status discrepancy, for example, a relatively high economic status but low social and political status, and status mobility, namely an increase or decrease in status, can also be determining factors in the creation of revolutionary potential. Upward mobility tends to increase revolutionary potential on the left, and downward mobility increases revolutionary potential on the right. ${ }^{11}$

\section{Geography and demography}

Increasing population pressures on limited agricultural resources, especially if leading to rural-urban migration where industrial development and employment opportunities lag behind urban population growth, increase both the potential for agrarian and urban violence. Urbanisation often also leads to a disintegration of traditional norms. Geography in turn could affect revolutionary potential in various ways. Geographic isolation can reduce the effect of the demonstration effect of revolutionary activity occurring in other countries. In geographic regions of a country that are subject to floods or famine, conditions conducive to revolutionary activities tend to exist. ${ }^{12}$

In addition and complementary to the above, perceived political inequalities, infringements of rights, existence of a tradition of violence; weak and inept government, and erosion of confidence in government, are further underlying factors that could contribute towards the potential for political violence, including terrorism and revolutionary warfare. ${ }^{13}$

As well as developing specific empirical determinants, in other words a set of indicators based on the actual incidence of revolution, various attempts have been made to develop theories or models of revolution, where the causes are presented in the form of theoretical constructs, which are more than the sum total of indicators based on the actual incidence of revolution. It has, however, been argued that in the strict sense of the word, there is no theory of revolution, but at most a conceptual framework which includes some middle-range independent hypotheses. The emphasis is therefore on tendency statements rather than invariable association or absolute certainty.

\section{Relative deprivation}

The concept of relative deprivation is seen as a psychological factor underlying revolution. It is described as a perception of discrepancy between value expectations and value capabilities, with the latter being found largely in the social 
and physical environment. Relative deprivation is also linked to the concepts of frustration and alienation. Deprivation may be personal or a group experience. The more severe and widespread the deprivation, the greater the possibility of violence. Awareness of the likelihood of interference in expectations may be as important as actual interference. Interference can take the form of impediments to the achievement of goals or interference with an existing condition. The articulation of an ideology may be related to deprivation, namely a generalised belief among the deprived. Often, a number of competing generalised beliefs exist. The locus of deprivation (among the masses or the elite) may also determine the nature of any subsequent civil violence. ${ }^{14}$

\section{The J-curve of rising expectations}

Related to the concept of relative deprivation and frustration-aggression, the so-called "J-curve" posits that a prolonged period of rising expectations and rising gratifications is followed by a short period of reversal, leading to a widening gap between expectations and gratifications. It combines a fear of loss and a fear that things will no longer continue to improve. ${ }^{15}$

The "J-curve" is also described as a psychological explanation, and a necessary, but not sufficient, part of the explanation of revolutions (and rebellions). It has also been said that it is not the destitute or the well-satisfied that revolt successfully, but those whose actual situation is not improving according to expectations. ${ }^{16}$

\section{The role of ideology and political motivation}

Ideology has been defined as a set of attitudes, values or beliefs about the way things are and ought to be, or as a guideline for action. Ideologies may be religious, political, social, etc, or combinations of these. Alternative ideologies which challenge the status quo and which may or may not incorporate some of the objective factors that contribute to revolutionary potential can therefore at least be seen as a contributory cause to revolution or the sustaining or justification of a revolution. In this context, nationalism (political self-determination), specific leftist ideologies such as Marxism and anarchism or reactionary ideologies such as neoFascism, religious fundamentalism, single issue beliefs such as those of violent animal rights groups, and state-sponsored terror or state-supported terror in the domestic or international arena, have been listed as typologies based on the underlying cause or political motivation. ${ }^{17}$

In addition to the underlying causes, certain factors may serve as more immediate accelerators or trigger factors, but these are not sufficient in the absence of more underlying causes. They could include military defeat for the incumbent 
government in a foreign war, sudden economic crisis, government violence and over-reaction to protestors, elite fragmentation, and the demonstration effect of other revolutionary campaigns. ${ }^{18}$

There is general consensus that certain preconditions must exist if a revolution is to commence. However, Che Guevara argued that only certain minimum preconditions need to exist, as the other preconditions could be created by initiating revolutionary action. The minimum conditions would be a lack of legitimacy of the incumbent elite, existence of tensions that cannot be resolved through normal channels, and the fact that all legal avenues to change are perceived as being closed. Therefore, certain actions by the insurgent groups could both create further conditions conducive to creating a revolutionary climate, and serve as a spark to ignite the revolution. Of course, leadership organisation and mobilisation would also be required subsequently to steer the revolution. ${ }^{19}$

\section{Violent protest at local level in South Africa: Opposing views}

The violent unrest at local government level has been viewed, on the one hand, as part of a wider problem that has the potential to develop into a revolution. While the more immediate problem is linked to the frustration of promises not kept regarding service delivery, the wider problem includes crime, the growing gap between rich and poor, and the deteriorating condition of government departments such as Home Affairs and Justice. The impression was created that government was not in control any longer, and this resulted in revolutionary potential being present. ${ }^{20}$

On the other hand, the view has also been expressed that, while civil society movements have grown and are leading municipal protests, they pose no immediate threat to the African National Congress (ANC). In this view, some of the protests were also personally motivated, for instance in the case of individuals who "did not make it on the ANC candidates list before the local elections". ${ }^{21}$

It was also estimated that there were currently about 6000 civil movements in South Africa, with the older organisations, such as the Treatment Action Campaign (TAC), more organised than the new social movements in townships. The latter are seen as "spontaneous and not formally organised". They are also small, sporadic and limited to smaller areas. They are also not linked to each other. ${ }^{22}$

It has furthermore been stated that the public violence associated with service delivery did not represent a fundamental threat to the stability of South Africa, and that it could be contained, although this would require adjustments to current policy and policy implementation. ${ }^{23}$ 
The fact that the Public Protector and the National Intelligence Agency (NIA) has been reported to have investigated the causes of recent service-delivery protests, and not only the South African Police Service (SAPS), could, however, of course point to the fact that the protests are not only viewed as law and order threats, but as national security threats, although the distinction between the two is not always clear. Allegations of "third-force" involvement in local protest actions of course offer another explanation for NIA involvement. In some of the cases, individuals linked to political parties such as the United Democratic Movement (UDM) and the Inkatha Freedom Party (IFP) have been implicated as instigating protest action. ${ }^{24}$ The Premier of Gauteng, Sam Shilowa, has on occasion also claimed that immigrants, and not locals, are involved in protests over poor service delivery. ${ }^{25}$

The protest march in Kliptown during 2007 involved the participation of several thousands of people from several informal settlements, contradicting the statement previously referred to, that the protest actions were small and not linked. In addition, the Landless People's Movement, as an example of more organised action, has represented residents of informal settlements in protest action at, for instance, the Department of Housing. During violent protest action in Sebokeng in August 2007, a member of the Anti-Privatisation Forum threatened to "burn down" the township if their grievances were not acted on and promises made 13 years ago still not carried out. It was also stated that the burning of townships in 1984 led to the fall of the National Party Government. ${ }^{26}$ In this regard, it has been stated that contrary to some official views, no evidence of a "third force" could be found in service-delivery protest actions, but that some protests were organised by local groups in similar ways in different areas, although there has not yet been clear evidence of premeditated co-ordinated action. ${ }^{27}$

Other arguments used to explain the violent nature of protest action, is that the violence is a reaction to police presence when the latter react to instances of vandalism or the blocking of roads. Traditions of the past are also offered as explanations, namely that people know that violence had an impact on achieving certain objectives in the past, and it was therefore a way of attracting attention. ${ }^{28}$

President Thabo Mbeki had, however, already indicated in Parliament in 2005 that poor service delivery could in the long run negatively affect the stability of South Africa. ${ }^{29}$ In 2006, there were 920 recorded cases of unrest related to poor service delivery in South Africa, and it was stated that if these incidents were well co-ordinated, it could cause major problems for the government. By September 2007, 40 violent protests had occurred in Gauteng alone. ${ }^{30}$ The ANC stated during 2007 that it was "deeply concerned" about service-delivery protests, and that some came from communities with genuine grievances while others were "politically" 
motivated. The dividing line between the two was, however, thin and both had to receive the same degree of attention. ${ }^{31}$

\section{An assessment of revolutionary potential linked to local protest}

A survey conducted among 8000 South Africans between April 2006 and April 2007, indicated that at least a third of the respondents were dissatisfied with local service delivery in metro areas. In smaller towns in Gauteng, the dissatisfaction increased to 44 per cent among black residents. In North West small towns, 38 per cent of white residents were dissatisfied. The average rate of dissatisfaction was 27 per cent, while it should generally be no more than 15 per cent in countries which have a generally satisfactory state of affairs. What was especially of concern was the high number of areas where people were "extremely dissatisfied". 32

During August 2007, the result of case studies of four municipalities that had experienced service-delivery protests during 2004-2005, was published. Poor communication with the communities, lack of transparency, poor governance, ineffective management and political infighting were found to be some of the main factors contributing to the protests. ${ }^{33}$ At the beginning of 2008, it was also found that more than half of the district and local municipalities were performing less than 50 per cent of the functions allocated to them. ${ }^{34}$

Linking service-delivery protests to rising expectations and relative deprivation, it has often been stated that it is in fact the failures of government (national and provincial) and the economy that has increased "the growing tension between the expectations and the reality of, or perceptions about, service delivery". In this type of explanation, expectations are not unrealistic, and neither should councillors be blamed for making false promises. The service-delivery protests are actually directed at government as a whole, and municipalities only happen to be the most immediate manifestation of government. Demands made by people were also not unreasonable, but they expect to be taken seriously by government. Councillors were also not playing a proper role as the "voice of the people" to government, and government's approach that councillors should be the voice of national government to the people, is wrong. ${ }^{35}$

That protest action could eventually result in incidents which resemble terrorism (with an overall political motive) and not only in certain acts of violence, is clear, as evidenced in the case of People against Gangsterism and Drugs (PAGAD) in South Africa in the 1990s. PAGAD eventually even acquired certain revolutionary overtones, indicating an attempt to escalate beyond certain more random acts of terror that could be linked to the organisation. PAGAD had been relatively inactive since the beginning of 2000 , but held a mass meeting in Cape 
Town in August 2007, stating that the police had failed residents regarding drug dealers and gangsters. Furthermore, they wanted all shebeens in the Western Cape to be closed down, rather than regulated. ${ }^{36}$ Other groups such as the People Anti-Drug and Liquor Action Committee (PADLAC) have also more recently emerged and staged protest marches. It was reported that the police were concerned about these activities, and stated that PADLAC was a vigilante group. ${ }^{37}$

In the case of the alleged Boeremag involvement in revolutionary activities, factors such as affirmative action and its effect on whites; high crime levels (also viewed as a process of "ethnic cleansing" because government is accused of condoning it); and depriving the Afrikaners of their identity, were provided as justifications. Some of these may be more subjective than others, but it is clear that it does point to the existence of some revolutionary potential. ${ }^{38}$

From the foregoing examples it seems clear that some of the basic preconditions for (violent) protest to become revolutionary (or at least develop into) what would constitute terrorism, even if it is sub-revolutionary terrorism not aimed at the violent overthrow of government or secession, do exist in South Africa. There is therefore a certain revolutionary potential. The seemingly ready availability of commercial explosives (as currently used to blow up automated teller machines) and illegal firearms, including automatic weapons, could also be incentives for acts of terrorism. Vast informal settlements all over the country make policing very difficult. On the other hand, organisation and leadership and a critical mass of supporters are among the main requirements for the formation of a revolutionary organisation. Violent protest, even if it becomes increasingly politically motivated (in other words more than aimed only at resolving immediate material grievances), may result in random acts of terror in certain circumstances, but relatively few terror campaigns become systematic or reach the stage of insurgency.

In South Africa especially, there are, however, also two other factors that have to be taken into account. First of all, unacceptably high crime levels (and especially violent crime) are also being seen as "service-delivery" failures (for example poor border control and an ineffective criminal justice system), while recent warnings about food riots in Africa especially, in view of food shortages and the spiralling cost of food, also relate to South Africa, and this has already led to organised protests. In fact, a relatively sudden economic crisis, such as the escalation in food and fuel prices, and the envisaged increase in electricity tariffs, could also resemble "trigger" factors that could lead to violent protest and beyond, if some of the underlying conditions for political violence (including the possibility of terrorism and wider revolutionary activity) do exist. In this regard, protest marches against the envisaged tariff increases for electricity have also already been staged in 
South Africa. It is, however, clear that poverty alone (which is often in general linked to terrorism and crime) is in fact seldom an explanation for violence and revolution. Other factors also need to be present. Hence, corrupt and ineffective governments, rising expectations and feelings of relative deprivation, to the extent that these form part of the causes of or pre-conditions for political violence and possible revolutionary activity, cannot be ignored.

Allegations of major corruption in government, in addition to poor service delivery, were for instance made by the IFP in a protest march that turned violent in September $2007 . .^{39}$ Perceptions (and the reality) of corruption and poor service delivery, clearly form a deadly combination. This was unambiguously stated by former African National Congress (ANC) chairperson, Mosiuoa Lekota, when he said that many "ambitious poor-quality 'comrades' occupy government positions, and some steal public funds because politics doesn't pay". ${ }^{40}$

In this regard, it was also recently stated again that, in addition to high degrees of poverty or unemployment, perceptions of corruption or perceptions of relative inequality are important in explaining service-delivery protests. Linking the current wave of violence directed at foreigners in South Africa with service delivery protests, it was stated that -

(t)he target of dissatisfaction around service delivery and perceived inequity, has therefore taken on the face of immigrants ... it can only be hoped that South Africans recognize the true course of discontent - contested resources; which can only be meaningfully addressed by accelerated service delivery. ${ }^{41}$

Furthermore, feelings of relative deprivation are specifically emphasised in the preceding views.

Residents who are poor (but not necessarily among the poorest in the country or even their municipality) compare themselves unfavourably with better-off residents or local politicians. Such comparisons raise frustration, with an event or series of events then providing a tipping point. Municipal IQ (a data and intelligence service on South African municipalities) believes that underlying poverty combined with an event or series of events may well explain the violence that has erupted across Gauteng. The relative wealth of Alexandra residents suggests that, in the case of Alexandra, it is a sense of relative deprivation or perceived inequality that raises feelings of dissatisfaction. ${ }^{42}$ 


\section{Conclusion}

That there is significant potential for political violence in South Africa, is clear. Whether it could escalate to more systematic acts of terror and culminate in revolutionary activity, is less clear. In both the case of PAGAD and the alleged "Boeremag" conspiracy, what amounts to revolutionary objectives were, however, formulated, although PAGAD initially focussed on specific grievances per se. Some incidents of violent protest that have occurred in South Africa over service delivery and especially if accompanied by an overall political motive, could in fact be viewed as acts of (at this stage random) terror. Whether the potential for this to develop into a broader insurgency exists, is debateable at this stage, but the existence of certain underlying conditions conducive to both political violence and the creation of revolutionary potential, is undeniable. The existence of specific trigger factors (such as food price increases) and the demonstration effect of violent protest and violent attacks (such as those on foreigners) are also evidenced by the contagion effect that violence in one area or province, seems to have on others.

\section{References}

1 Greene, T H, Comparative Revolutionary Movements, Prentice-Hall, New Jersey, 1974, pp. 6-7.

Wilkinson, P, Terrorism and the Liberal State, Macmillan, London, 1977, p. 32 .

Baylis, J, "Revolutionary Warfare", in Baylis, J, et al., Contemporary

Strategy, Vol 1, $2^{\text {nd }}$ edition, Croom Helm, London, 1987, pp. 211-212.

Snow, D M, Uncivil Wars, Lynne Rienner Publishers, London, 1996, p. 66 .

Ibid.

Baylis, J, "Revolutionary Warfare”, op cit, pp. 212-224; Greene, T H, op. cit., pp. 61, 79 and 97; and Wilkinson, P, 1977, op. cit., pp. 108-109.

Wilkinson, P, Terrorism Versus Democracy: The Liberal State Response, Frank Cass, London, 2001, pp. 14-16; and Wilkinson, P, 1977, op. cit., pp. 109 and 110 .

Greene, T H, op. cit., pp. 124-128. 
Ibid., pp. 128-135.

Wilkinson, P, 1977, op. cit., pp. 37-38.

Greene, T H, op. cit., pp. 142-143

Ibid., pp. 120-122.

Wilkinson, P, 1977, op. cit., pp. 37-38.

Gurr, T, "Psychological Factors in Civil Violence", in Sarkesian, S C (ed.), Revolutionary Guerrilla Warfare, Precedent Publ Inc, Chicago, 1975, pp. 81-83.

Davies, J C, "The J-curve of Rising and Declining Satisfaction as a Cause of Some Great Revolutions and a Contained Rebellion”, in Sarkesian, S C (ed.), op. cit., p. 117.

Ibid., p. 136; and Green, T H, op. cit., p. 132.

Wilkinson, P, 2001, op. cit., pp. 19-21.

Greene, T H, op. cit., pp. 104-118.

Wilkinson, P, 1977, op. cit., p. 100; and Moreno, J, "Che Guevara on Guerrilla Warfare", in Sarkesian, S C (ed.), op. cit., p. 396.

Beeld (Johannesburg), 16 July 2007.

Business Day (Johannesburg), 17 September 2007.

Ibid.

Beeld (Johannesburg), 17 July 2007.

Business Day (Johannesburg), 27 July 2007; and Beeld (Johannesburg), 17 August 2007.

Beeld (Johannesburg), 2 August 2007.

Beeld (Johannesburg), 28 September 2007.

Business Day (Johannesburg), 20 May 2008.

Beeld (Johannesburg), 17 July 2007.

Beeld (Johannesburg), 7 June 2005.

Beeld (Johannesburg), 11 September 2007 and 2 November 2007. 
Business Day (Johannesburg), 17 July 2007.

Business Day (Johannesburg), 24 July 2007.

Business Day (Johannesburg), 13 August 2007.

Beeld (Johannesburg), 19 March 2008.

Business Day (Johannesburg), 27 July 2007 and 30 July 2007.

Independent Online, "Pagad warned not to take law into own hands", 27 September 2007. (Available online at: www.iol.co.za).

Independent Online, "Ramatlakane warns Padlac "vigilantes", 26 September 2007. (Available online at: www.iol.co.za).

Interim Government of the South African Boer Republics, Proclamation 1, 11 July 2002.

Beeld (Johannesburg), 26 October 2007.

Independent Online, "Lekota warns on ANC greed and theft", 19 August 2007. (Available online at: www.iol.co.za).

Business Day (Johannesburg), 20 May 2008.

Ibid. 